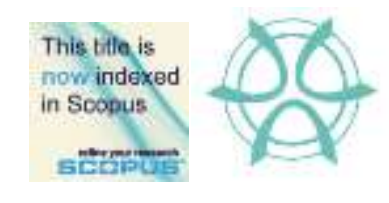

\title{
THE TRANSFORMATION FROM RESIDENTIAL TO COMMERCIAL SPACE TOWARDS DYNAMIC SPACE FORMATION IN CENTRAL JAKARTA
}

\author{
Ragil Haryanto ${ }^{1}$, Indriastjario ${ }^{2}$, Khuruin Saidah ${ }^{3}$, Agung Sugiri ${ }^{4}$ \\ 1, 3, 4 Department of Urban and Regional Planning, \\ ${ }^{2}$ Department of Architecture \\ Faculty of Engineering \\ DIPONEGORO UNIVERSITY, INDONESIA
}

\begin{abstract}
This research was conducted to examine dynamic space formation using urban space converts from housing to Small and Medium-size Enterprise (SME) commercial space in the street corridors of major cities in Indonesia. The study is necessary due to the rapid increase in population, observed to be affecting the urban socio-economic and physical aspects as evident with the sporadic growth of small and medium businesses in potential locations of urban street corridors where many plots of land for residential space have converted for commercial activities. The driving factors include business climate change, global economic crisis, democratic development, and decentralization of the economic sector. Indepth field research was conducted concerning the changes in space use in Bendungan Hilir area of Tanah Abang, Central Jakarta as a sample. Deductive thinking with purposive strata area sampling and natural settings without manipulating the subjects studied were applied as the methods. Meanwhile, data were collected quantitatively and qualitatively from one collector street corridor in the residential area observed to have shifted and changed to an SME commercial area. The results, therefore, showed a dynamic pattern of commercial activity leading to a "spatial democracy" pattern.
\end{abstract}

Keywords: land-use change, urban space shifting, sporadic growth, dynamic space, spatial democracy

\footnotetext{
${ }^{1}$ Assoc Professor at Diponegoro University. Email: ragil.haryanto@pwk.undip.ac.id
} 
Ragil Haryanto, Indriastjario, Khuruin Saidah, Agung Sugiri

The Transformation from Residential to Commercial Space Towards Dynamic Space Formation in Central Jakarta

\section{INTRODUCTION}

The physical development of big and medium cities in Indonesia has been very fast as observed in the changes in old spaces to perform modern functions and lateral expansion of the city (Passoneau in Roger, 2005; Haryanto, Soetomo, Bukhori, 2017). There are also other relatively rapid changes which are beyond the expectations of the original plan for the spatial functions as observed with the emergence of commercial activities in the areas initially planned for housing and settlements, especially along the main corridors and interconnected street lanes being used as residential space (P, Acero, K. Cabas, C. Caycedo, P. Figueroa, 2020; Lazim \& Said, 2020). The same phenomenon has been apparent in the downtown area of Jakarta, especially in Bendungan Hilir including Tanah Abang district located behind the main street corridor of the city - Jenderal Sudirman street.

\section{RESEARCH BACKGROUND}

\section{Research Approach}

This research intends to determine the fundamental link between urban spatial patterns and the phenomenon of developing commercial areas in the main urban street corridor dominated by retail small-medium businesses (Kostof, 1991; Lazim \& Said, 2020)). From the perspective of the scientific framework, the study ontologically presents objectivity but focuses on historical realism through observed or virtual reality which is considered pseudo in evaluating city development due to social, cultural, political, and economic forces (OECD, 2007, Cuervo, 2007, Venkataraman, 1997, and Fazal, Geertman, \& Toppen, 2012; Lazim \& Said, 2020). Meanwhile, epistemologically, the understanding of objectivity is modified, interactive, neutral, and also estimated to be dependent on criticism, therefore, this research was more inclined to the post-positivistic approach conducted deductively to implement the Critical Theory built based on previous research. This study is considered necessary due to its objectivity and reliance on the criticism of the transformation of socio-economic changes in society to determine the actual conditions (Tashakkori, 2003, Salim, 2006, and Creswell, 2007).

\section{Research methods}

The research was conducted as deductive thinking using purposive sampling with natural settings without manipulating the subjects. Data were collected at a collector's street corridor in the Bendungan Hilir area of Central Jakarta where space has massively converted to an SME Commercial area.

\section{Research Stages}

This research's Stage I was Field observation (Gold, 1958, in Tashakkori, 2010, and Turner and Johnson, 2003), which is a direct observation of all participants 
including small and medium businesses participating socially in a natural or built environment. The object of observation was the implication of using residential space along the urban collector lane for small, medium-sized retail, commercial activities. The homogeneity of these activities was, however, considered by deepening "field observations" in several areas with relative specific and unique characteristics including historical and philosophical value developed due to the influence of growth centres with specific activities, such as education and industry (Lazim \& Said, 2020). Moreover, existing activities were estimated to have the ability to support each other or relatively have a similar consumer market or mutual interaction, thereby, leading to their selection as areas with high potential as a spatial analysis unit for further research.

Stage II: Open interviews were conducted by "purposive sampling" using non-probability techniques such as the selection of directed samples not based on statistical formulations including a) convenience, b) judgment and c) snowballing which is a semi-structured interview activity with selected retail business actors in each cluster group. The results of the analysis, related to the field facts, were likely to raise further questions such as 'are there any dominant factors affecting the development of the spatial/spatial aspects? 'Are there other factors such as ease of doing business, political system and administration of local governance to provide a sense of security and comfort to the community affecting small and medium retail businesses development in line with the spatial patterns to provide business opportunities? These questions, therefore, led to the mixture of qualitative historical into descriptive analysis to obtain complete results.

Stage III: This is the synthesis stage through which the results were formulated with due consideration for field reality and the theories related to the synthesis of expected spatial patterns in each city.

\section{LOCATION ORIENTATION}

Bendungan Hilir is one of the essential areas in Jakarta which is strategically located around Semanggi Bridge and included in Tanah Abang District, Central Jakarta. It covers an area of $1.58 \mathrm{~km} 2$ which is approximately $16.99 \%$ of the whole district and directly bordered by three main street corridors including Jalan Jenderal Sudirman, Jalan Penjernihan, and Jalan Gatot Subroto and on the northern part by the Krukut River. The research area is surrounded by nationalscale commercial areas including trade-services and offices such as the Sudirman-Thamrin Prospective Economic Zone, Tanah Abang Industrial Center, and Kuningan-Sudirman-Casablanca Integrated Trade Center. Bendungan Hilir Zone is also designated as a supporting area for commercial and industrial activities in the Jakarta Capital City Design Guide. 
Ragil Haryanto, Indriastjario, Khuruin Saidah, Agung Sugiri

The Transformation from Residential to Commercial Space Towards Dynamic Space Formation in Central Jakarta

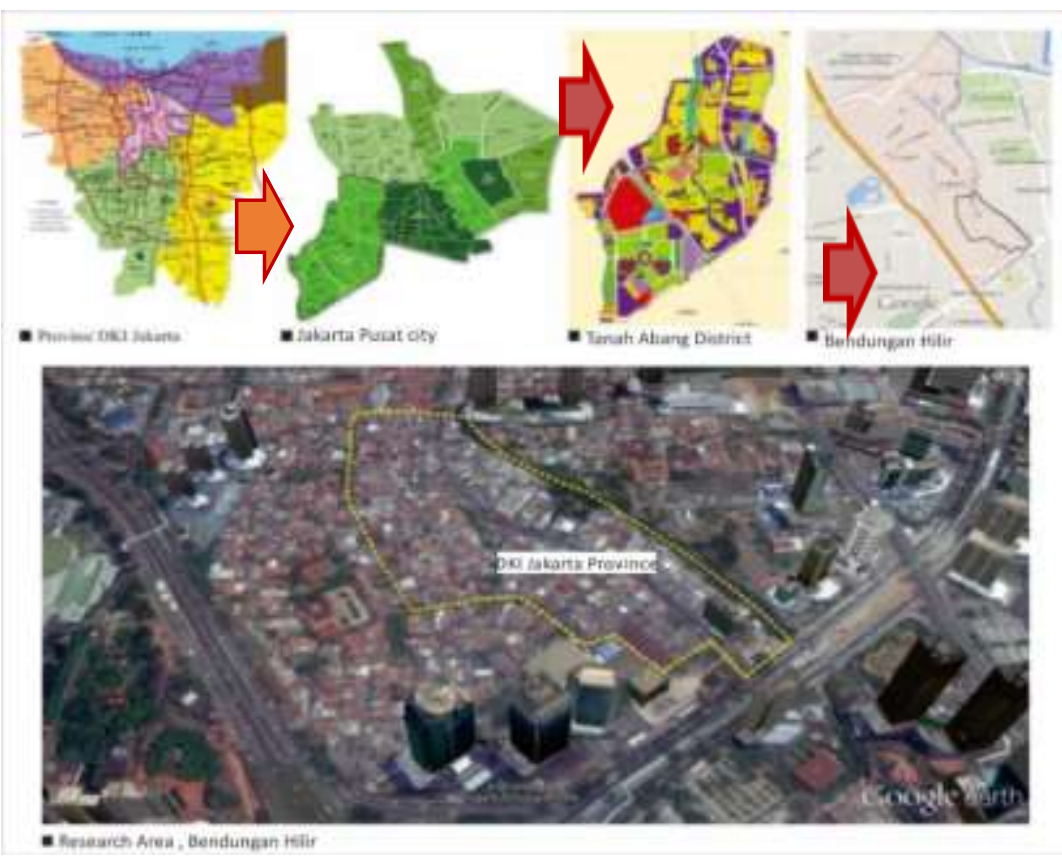

Figure 1: Research Location in Bendungan Hilir Area Source: Digitized on the Google map by the research team, 2019

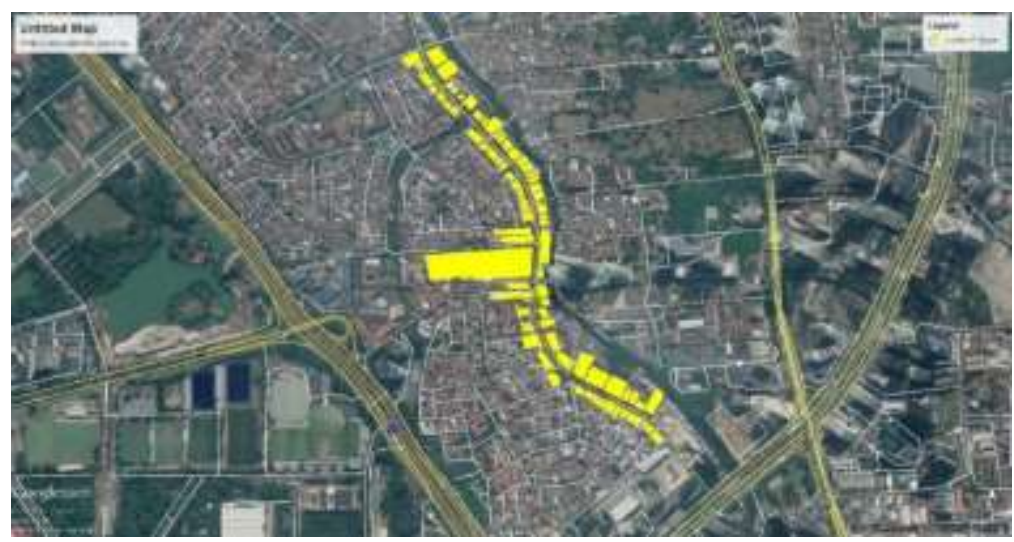

Figure 2: The Commercial corridor in Bendungan Hilir Street Source: Digitized on the Google map by the research team, 2019

Table 1: Land use, FAR, Elevation and BCR at the Special Area for Jakarta

\begin{tabular}{|c|c|c|c|}
\hline \multirow[t]{2}{*}{ Land Use } & $\begin{array}{c}\text { Floor Area } \\
\text { Ratio (FAR) }\end{array}$ & Elevation & $\begin{array}{c}\text { Building Coverage } \\
\text { Ratio (BCR) }\end{array}$ \\
\hline & Min & Min & Max \\
\hline
\end{tabular}


PLANNING MALAYSIA

Journal of the Malaysia Institute of Planners (2020)

\begin{tabular}{lcccccc}
\hline Mixed-Use & 0.8 & 1.6 & 2 & 4 & $20 \%$ & $40 \%$ \\
\hline Office Buildings & 0.8 & 3.5 & 2 & 8 & $20 \%$ & $60 \%$ \\
\hline Commercial Buildings & 0.8 & 2.4 & 2 & 4 & $20 \%$ & $60 \%$ \\
\hline Government centres & 0.4 & 2.4 & 2 & 4 & $10 \%$ & $60 \%$ \\
\hline Public Green Space & 0.1 & 0.2 & 1 & 2 & $2.5 \%$ & $5 \%$ \\
\hline Educational Institutions & 0.4 & 3 & 2 & 8 & $5 \%$ & $40 \%$ \\
\hline Sport Centre & 0.05 & 1.6 & 1 & 4 & $1.25 \%$ & $40 \%$ \\
\hline Cultural Buildings & 0.8 & 1.6 & 2 & 4 & $20 \%$ & $40 \%$ \\
\hline Worship facilities & 0.4 & 2 & 2 & 4 & $10 \%$ & $50 \%$ \\
\hline Health Institutions & 0.8 & 1.6 & 2 & 8 & $10 \%$ & $37.5 \%$ \\
\hline Single House Building (large) & 1.2 & 2 & 1 & 4 & $20 \%$ & $60 \%$ \\
\hline Residential (medium) & 1.2 & 1.2 & 1 & 3 & $20 \%$ & $60 \%$ \\
\hline Residential (small) & 1.2 & 1.2 & 2 & 2 & $60 \%$ & $60 \%$ \\
\hline Vertical Housing & 0.8 & 3.5 & 8 & 8 & $3.33 \%$ & $31.25 \%$ \\
\hline & & & Source: Special Area of The Capital Province, 2019
\end{tabular}

\section{Land Prices at the Research Location}

The following land price map is the result of a survey conducted by the National Land Agency in Bendungan Hilir area based on prevailing market prices at the time. The comparison of the two maps showed the price of the lands located on the edge of Bendungan Hilir street corridor is higher than those in Bendungan Hilir zone and an increase has also been there between 2013 and 2018 with variations based on respective locations.

Table 2: Land price in Bendungan Hilir Area, 2013 - 2018

\begin{tabular}{clcc}
\hline \multirow{2}{*}{ No } & \multirow{2}{*}{ Area } & \multicolumn{2}{c}{ Land Price Rp/ $\mathbf{m}^{\mathbf{2}}$} \\
\cline { 3 - 4 } & & $\mathbf{2 0 1 3}$ & $\mathbf{2 0 1 8}$ \\
\hline 1 & Front side Bendungan Hilir Street corridor & $22,213,000$ & $26,140,000$ \\
\hline 2 & Streetside Bendungan Hilir Street corridor & $17,496,000$ & $26,640,000$ \\
\hline 3 & Inside the area & $8,651,000$ & $16,540,000$ \\
\hline \multicolumn{2}{c}{ Source: BPN SPECIAL AREA OF THE CAPITAL Jakarta in 2015, and reprocessed in 2018}
\end{tabular}


Ragil Haryanto, Indriastjario, Khuruin Saidah, Agung Sugiri

The Transformation from Residential to Commercial Space Towards Dynamic Space Formation in Central Jakarta

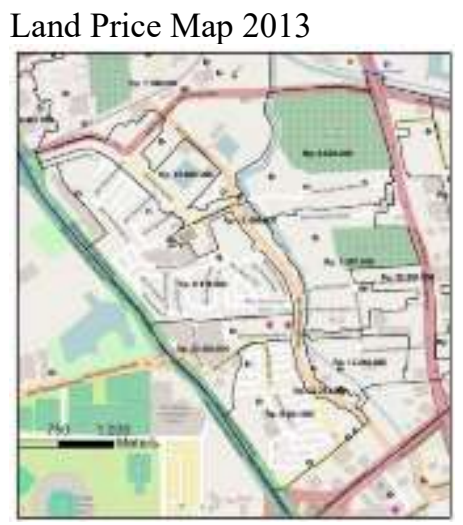

Land Price Map 2018

Figure 3: Land Price Map, Bendungan Hilir Area, 2013-2018 Source: Land Price Map BPN

\section{Spatial Planning at the Research Location}

The land allotment policy was studied to determine the development of spatial use planning by the Special Area of The Capital Jakarta Government in Bendungan Hilir area and four planning products were found to be relevant and considered to have a relationship between spatial use and research location. They include:

A. Spatial Planning of Special Area of the Capital Jakarta for 2010 - 2030

Bendungan Hilir area was found to have been selected for trading, office, and service activities while a housing system for low-income people, rejuvenation of the old market, and regulation of public transportation modes were also designed to be implemented. The land-use plan for the stipulated period was as a residential area to support the prospective economic zones and also designated as a public building area in places intersecting with Jalan Sudirman and Jalan Gatot Subroto.

B. Revision of Spatial Detailed Plan for the Sub District of Tanah Abang 2010-2030

This spatial planning product is a revision of the Spatial Detailed Plan for the Sub District of Tanah Abang for 2000-2005 under the spatial regulations for the 20102030 Special Area of the Capital Jakarta. This revised product has not been legalized but has become a material to prepare for the 2014-2034 Spatial Planning and Zoning Regulations for Special Area of the Capital Jakarta as stipulated in the Regional Regulation of Special Area of the Capital Jakarta Number 1 of 2014. Bendungan Hilir Area was planned in this regulation to serve as work and residential uses with their respective facilities.

C. Detailed Spatial Planning and Zoning Regulations for Special Area of the Capital Jakarta 2014-2034 
PLANNING MALAYSIA

Journal of the Malaysia Institute of Planners (2020)

The Spatial Detail Plan and Zoning Regulations are the operational provisions of Spatial Planning for the Special Area of the Capital Jakarta 2030, which regulates the utilization and control of space, based on zoning and designation of subzones. It covers all the sub-districts in five Administrative Cities and one Administrative District in Special Area of The Capital Jakarta. It establishes through the Provincial Regulation of Special Area of the Capital Jakarta Number 1 of 2014 concerning Detailed Spatial Planning and Zoning Regulations.

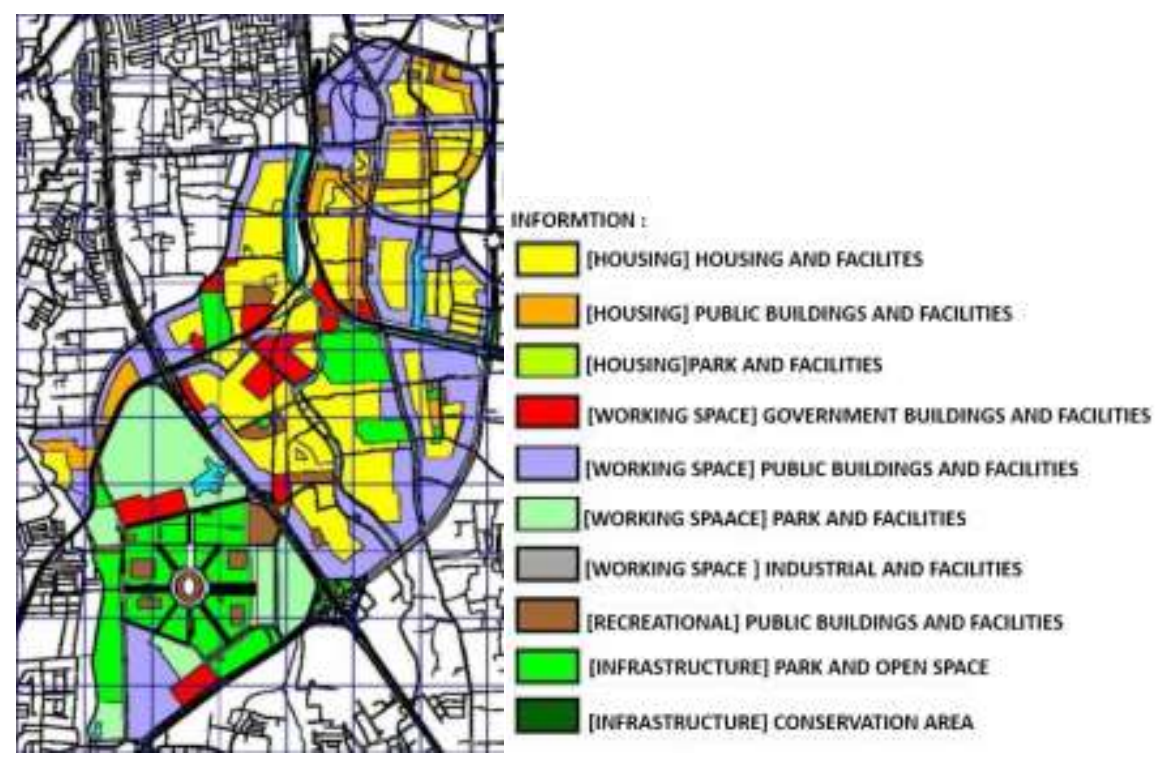

Figure 4: Spatial Zoning Regulations of the Special Area of the Capital Jakarta Source: Special Area of the Capital Province Attachments, 2013 
Ragil Haryanto, Indriastjario, Khuruin Saidah, Agung Sugiri

The Transformation from Residential to Commercial Space Towards Dynamic Space Formation in Central Jakarta
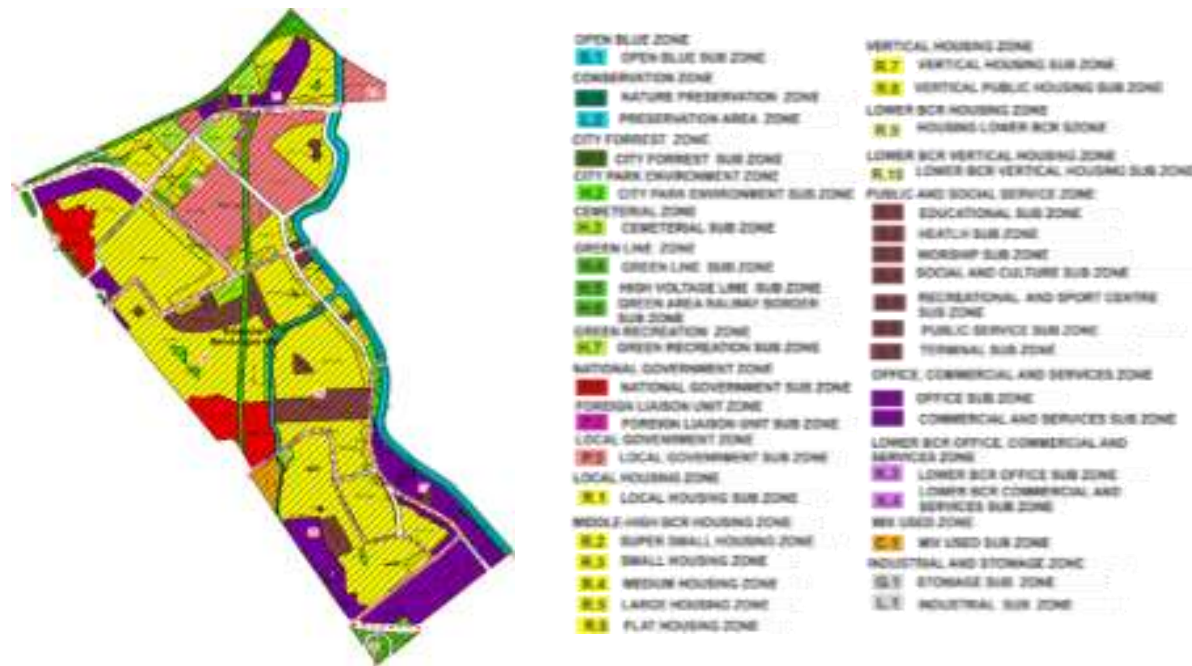

Figure 5: Spatial Detailed Plan for Bendungan Hilir Area, the Sub District of Tanah Abang

Source: Special Area of the Capital Province Attachments ,2019

D. City Design Guide for Bendungan Hilir - Mas Mansyur for 2012-2022

This design was determined in line with the Governor Regulation Special Area of Capital Jakarta number 176 of 2012 based on the following considerations:

a. Space is to be used as the centre of trade, offices and services, especially for business and shopping centres according to City Design Guidelines.

b. The strategic position of Bendungan Hilir - Mas Mansyur as an area passed by two main corridors including Sudirman which connects Thamrin and Sisingamangaraja streets as well as K.H corridor which connects Mas Mansyur with Prof. Dr Satrio street

The Design Guide shows a difference in the magnitude of the outbreak intensity values between the plans set out in the 2005 Sub District Spatial Detailed Plan and the existing conditions in 2008 as related with the spatial use in the Tanah Abang District. The section majorly affected are, therefore, offices, trade, education, sports, social culture, places of worship, health facilities, and flats as indicated by the ratio of maximum building heights.

The differences observed in the plan and current real conditions indicate the freedom of the people in utilising their properties as well as the dynamic spatial conditions (Anwar, 2002; Wang, 2012) shown in the appearance of the building function. This situation is understandable because different people own the properties, and this means the land values and the period of construction differ (Zainuddin \& Yusof, 2020). 


\section{RESULTS AND DISCUSSION}

The building intensities of the plan for trade, office, and residential functions in the Bendungan Hilir area was found to have a maximum FAR value of $60 \%$ while the value for buildings located on the edge of the street at 2008 when the Sub District Spatial Detailed Plan was revised was found to be up to $80 \%$. The findings show the planning efforts at the time paid less attention to the real conditions in the field, and this led to the fear of applying the plan. Another aspect, the suitability of the FAR values between the plans and field conditions in 2008 can be seen in the following table:

Table 3: Scheme and Existing Floor Area Ratio

\begin{tabular}{lcc}
\hline \multirow{2}{*}{ Land Use } & \multicolumn{2}{c}{ Floor Area Ratio (FAR) Maximum } \\
\cline { 2 - 3 } & $\begin{array}{c}\text { Sub District Spatial } \\
\text { Detailed Plan 2005 } \\
\text { (Scheme) }\end{array}$ & Existing \\
\hline Office Buildings & $>5.0$ & 3.5 \\
\hline Commercial Buildings & $>5.0$ & 2.4 \\
\hline Government centres & 3.0 & 2.4 \\
\hline Educational Institutions & 2.4 & 3 \\
\hline Sport Centre & 1.2 & 1.6 \\
\hline Cultural Buildings & 1.2 & 1.6 \\
\hline Worship facilities & 1.2 & 2.4 \\
\hline Health Institutions & 1.6 & 2 \\
\hline Single House Building (large) & 3.0 & 1.2 \\
\hline Residential (medium) & 1.2 & 1.2 \\
\hline Residential (small) & 1.2 & 3.5 \\
\hline Vertical Housing/Flat & 3.0 & Source: Authors' Analysis, 2019
\end{tabular}

Table 4: Scheme and Existing Elevation Maximum

\begin{tabular}{lcc}
\hline \multirow{2}{*}{ Land Use } & \multicolumn{3}{c}{ Elevation Maximum } \\
\cline { 2 - 3 } & $\begin{array}{c}\text { Sub District Spatial Detailed Plan } \\
\text { (Scheme) }\end{array}$ & 2005 \\
\hline Office Buildings & $>32$ & 8 \\
\hline Commercial Buildings & $>32$ & 4 \\
\hline Government centres & 4 & 4 \\
\hline Educational Institutions & 4 & 8 \\
\hline Sport Centre & 2 & 4 \\
\hline Cultural Buildings & 2 & 4 \\
\hline Worship facilities & 2 & 8 \\
\hline Health Institutions & 4 & 4 \\
\hline Single House & 2 & 4 \\
Building(large) & & 4 \\
\hline
\end{tabular}


Ragil Haryanto, Indriastjario, Khuruin Saidah, Agung Sugiri

The Transformation from Residential to Commercial Space Towards Dynamic Space Formation in Central Jakarta

\begin{tabular}{lll}
\hline Residential (medium) & 4 & 3 \\
\hline Residential (small) & 2 & 2 \\
\hline Vertical Housing/Flat & 4 & 8 \\
\hline & \multicolumn{2}{c}{ Source: Authors' Analysis, 2019 }
\end{tabular}

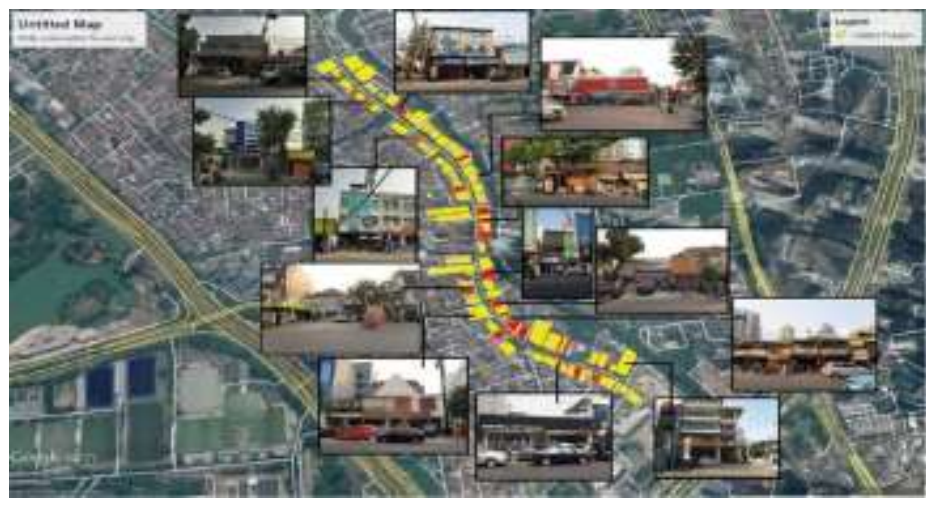

Figure 6: Land Use, Building Condition Bendungan Hilir Street Source: Authors' Analysis, 2019

The utilization of space and building along the Bendungan Hilir Street corridor has been a mix, with several buildings performing different functions such as office, trade, household, photocopy and printing, culinary and restaurant as well as hospitals and mosques. This situation means that most of the buildings along the corridor have changed from being used for residential functions to nonresidential or commercial functions. Moreover, the average FAR value was included in the high category at approximately $80 \%$ while the building height conditions ranged between 1 to 5 floors with those used for trades and services having 2 to 4 floors. Meanwhile, the other street in the area also has buildings which are used for trading and services with small lots having 1-2 floors while those on Jatiluhur Street perform a residential function with an average height of 2 floors.

The field facts and secondary data showed significant differences in the function of the utilization and activities, land values, and building height required in line with the regulations. The variations can be associated with:

(1) the difference in the ownership status of the properties and purpose or objectives of the businesses;

(2) the utilization of properties has not been considering the regulations, mainly due to the difference in economic capabilities and time needed for the development process.

It, therefore, means there is a possibility of changes in the function of any city at any time depending on the economic support (Elhorst, 1996) provided by the owners or tenants of the property and most importantly the strength of the applicable spatial planning regulations. 
The utilization of residential space located close to the commercial area of the city was, therefore, observed to be quickly affected by changes in functions, thereby, tending to lead to the freedom and dynamic use of space, especially in situations where spatial regulations are not strongly set.

\section{Democratic Spatial Pattern: A Concluding Remark}

There is a dynamic shift in the development of city space which seems to be static in reality (Anwar, 2002 and May \& No, 2015). The data used in this study is static or secondary, and this means primary data obtained from the field was required due to its continuous change. Moreover, spatial arrangement is directly related to the land or earth, which is static, never shifts an inch but has the ability dynamically generate community activities. In line with the principle of democracy being politically practised in Indonesia, reference was made to previous research by Haryanto, Soetomo, and Bukhori (2017) where the democratic spatial pattern means that the space creations are through democratic processes and observed to be different from those created by non-democratic actions such as social processes where there is no individual ownership or equal use of space by individuals. Democratic spaces are, therefore, usually used for public or democratic activities.

Field analysis and the emergence of the development of commercial activities along the Bendungan Hilir Street corridor as well as the number of small and medium commercial business activities paying rents instead of owning place showed the lack of permission to erect buildings for businesses in the area. Some were also discovered to be using old licenses and building permits for housing. Business spaces were, however, found to have been developed freely due to the difference in spatial utilization direction compared to the development, and this further indicates people's democratic spaces in business. Therefore, there is a need to democratize spatial arrangement, especially in terms of ownership and use of land.

\section{ACKNOWLEDGEMENTS}

The authors appreciate the Diponegoro University for funding the development and implementation of this research. Also grateful to all parties that have a contribution to the completion of this research, especially the Department of Urban and Regional Planning, and the Institute of Research and Community Service at Diponegoro University where the research was conducted.

\section{REFERENCES}

Anwar, Sk. Morshed, 2002, Land Use Change Dynamics: A Dynamic Spatial Simulation, thesis, Asian Institute of Technology School of Advanced Technologies, Thailand, December 2002

Caves, W, Roger. 2005, Encyclopedia of the City, Routledge, London-New York 
Ragil Haryanto, Indriastjario, Khuruin Saidah, Agung Sugiri

The Transformation from Residential to Commercial Space Towards Dynamic Space Formation in Central Jakarta

Creswell, J. W, 1998, Qualitative inquiry and research design: Choosing among the five traditions. Thousand Oaks, CA: Sage.

Cuervo, Alvaro; Ribeiro, Domingo; Roig, Salvador (2007) Entrepreneurship: concepts, theory and perspective, Springer, Berlin

Elhorst, JP, 1996, Dynamic Models in Space and Time, SOM-Theme C: Coordination and growth in economies, Faculty of Economics, University of Groningen, P.O. Box 800, 9700 AV Groningen, The Netherlands.

Fazal, S., Geertman, S. C. M., \& Toppen, F. J. (2012). Interpretation of Trends in Land Transformations - A Case of Green Heart Region (The Netherlands). Natural Resources, 03(03), 107-117. https://doi.org/10.4236/nr.2012.33015

Gold, R. 1958. Roles in sociological field observation. University of North Carolina: Social Forces.

Haryanto, Soetomo, Bukhori, 2017, A Phenomenon of Spatial Economic Democracy: Emerging Small-Medium Enterprises along the Street Corridors of Yogyakarta, Indonesia, Journal of Settlements and Spatial Planning

Haryanto, 2018, Spatial Transformation of Democratized into Liberalized Commercial Area in the Street Corridors of Yogyakarta, Indonesia, Advanced Science Letters

Johnson, B., \& Turner, Lisa. A. (2003). Data collection strategies in mixed methods research. In A. Tashakkori \& C. Teddlie (Eds.), Handbook of mixed methods in social and behavioral research (pp. 297-319). Thousand Oaks, CA: Sage.

Lazim, F. S. M., \& Said, S. Y. (2020). Townscape appraisal and contribution of physical features towards the character of ipoh old town. Planning Malaysia, 18(2), 97108

Marshall, Stephen, 2005, Urban Pattern Specification, Institute of Community Studies, London

May, O. G., \& No, R. (2015). Inclusive Cities Approach Paper 1. (May), 1-86.

OECD, 2007, Competitive Cities, A New Entrepreneurial Paradigm in Spatial Development, Organisation for Economic and Development Publishing,

P, Acero, K. Cabas, C. Caycedo, P. Figueroa, G. P. \& M. R. (2020). No Title. 18(2), 261272. Retrieved frohttp://repositorio.unan.edu.ni/2986/1/5624.pdf

Salim, Agus. 2006. Teori dan Paradigma Penelitian Sosial. Yogyakarta: Tiara Wacana

Tashakkori, A., \& Teddlie, C. (2010). Mixed methodology: Combining qualitative and quantitative approaches, Applied Social Research Methods, No. 46

Venkataraman, S .1997. The Distinctive Domain of Entrepreneurship in Katz, J.A. (Ed.), Advances in Entrepreneurship: Firm Emergence and Growth, 3, pp. 119-38.

Wang, Xiaokun (Cara); Kockelman, M, Kara; Lamp, D, Jason; 2012, The Dynamic Spatial Multinomial Probit Model: Analysis Of LandUse Change Using ParcelLevel Data, Journal of Transport Geography No. 24; 77-88, 2012

Zainuddin, Z., \& Yusof, R. M. (2020). Do inflation, interest rate and cost of renting affect the price of terrace houses in Penang? Planning Malaysia, 18(3), 337-347. https://doi.org/10.21837/PM.V18I13.797 